\title{
Outstanding Leadership Characteristics of Chinese Fast Growing Enterprises
}

\author{
Zhou Yu \\ Business School, Hohai University, Nanjing, 211100,China
}

Keywords: Leadership, Fast growing, Characteristics, Traditional Chinese management thoughts.

\begin{abstract}
There have appeared two types of Chinese enterprises which play an important role in the country's social and economic development. One kind are established mainly by government and the other grow up simultaneously with Chinese market economy. How to make the first kind head for fast growing and second kind sustain it is an important subject of current management of Chinese enterprises. Choosing Haier, Lenovo and Huawei as research cases, this thesis proposes theoretical hypotheses from the influence of traditional Chinese management thoughts on Chinese business management, uses interpretative multiple case study to test and verify the hypotheses, draws the conclusion of outstanding leadership characteristics of fast growing enterprises.
\end{abstract}

\section{Introduction}

Chinese enterprises are now facing a high uncertainty competitive environment. Two types of enterprises play an important role on Chinese social and economic development under global competition. The first kind of enterprises were established mainly by government in the process of transformation of government functions. Such enterprises are large-scale, many of which have been listed in "Fortune" global 500, but they are more engaged in the domestic business, lack of strong international competitive advantage, such as Sinopec. The second category are those enterprises growing with development of Chinese market economy, such as Haier, Lenovo and Huawei. Though such enterprises have short history, they already have certain competitiveness in the global market because of early participation in international competition. They all have "fast growing" characteristics. How to promote the first kind of enterprises moving forward to fast growing and keep the second kind maintaining fast growing is an important topic of Chinese business management research. Based on research of successful enterprises and their growing, we choose "characteristics of fast growing enterprises" as a subject for specific study.

Enterprise growth theory research and successful enterprise research always attract attention of many researchers (Collins etc, 2006; Huang, 2014; Hu, 2015; Fisher,etc, 2015; Li,2015). First researchers study enterprise growing from economics standpoint. Penrose(1959) for the first time, introduced management function into firm growth theory and brought forward a analytical framework of resource- capability-growth. Under conditions of social and economic transformation, the rise and rapid development of Chinese large-scale enterprises provide a good practical foundation for Chinese management research. Chinese enterprise growth-related research vigorously develops. Current study on Chinese successful enterprises mainly focuses on multiple characteristics of single enterprise or single characteristic research of multiple enterprises. Ouyang etc made series study on the growth of Haier. Lan etc(2011) conducted a research on fast growing of newly created enterprises, taking TCL International Electro-technical as an example. Li etc(2009) explored marketing strategy characteristics based on 10 successful enterprises. Mao etc carried out cases research of Galanz electrical appliance and TCL color TV production systems, Chigo air-conditioning manufacturing systems, Donlim kitchen group and Jasic Technology upgrade strategy. Chen, etc(2014) analyzed input and output factors of fast growing for Chinese industry pioneer. Kang etc(2006) made niche strategy research. Zeng etc (2008) made low cost innovation research. As well as there are scholars' researches of technological innovation (Xu, 2012) and management innovation (He etc, 2009). 
Reviewing the existing researches, we can find that they explored characteristics and causes of successful enterprises based on modern management theories. To Chinese indigenous research, we shall first admit that Chinese traditional management thoughts play non ignorable impact on present Chinese business management. Chinese traditional management thoughts and modern western management theories together created today's Chinese enterprises. From this view, we may ask, in addition to existing researches, what other characteristics and causes do Chinese successful enterprises have? Thinking influence of Chinese traditional management thoughts on Chinese business management provides directional guidance for this research. This research focuses on the outstanding entrepreneurs of successful enterprises, seeking and proving the characteristics of entrepreneurs for fast-growing of Chinese enterprises under Chinese context.

\section{Research Design}

Adopting interpretative multiple case study(Yin, 2004) and choosing Haier, Lenovo, Huawei as core cases, this thesis first proposes theoretical hypotheses, then demonstrates the hypotheses by multiple cases analysis with secondary data, then draws the conclusions. Case data collection emphasizes comprehensive exploring evidence from history, attitude and behavior. Therefore, the main sources of data include articles, books, interviews, speeches, meeting minutes, enterprise internal publications, annual reports, official websites and other materials related to enterprise management, as well as scientific research of scholars.

Table 1: Case Enterprise Profile

\begin{tabular}{|l|l|l|l|l|}
\hline Name & $\begin{array}{l}\text { Founding } \\
\text { Date }\end{array}$ & Industry & Industry Ranking & Leader \\
\hline Haier & 1984.1 .1 & $\begin{array}{l}\text { Electronic and } \\
\text { electrical } \\
\text { equipment }\end{array}$ & $\begin{array}{l}\text { Global No.1 white household electrical } \\
\text { appliance brand; global No.4 white } \\
\text { household electrical appliance maker; } \\
\text { domestic market share surpasses 25\% } \\
\text { for many years. }\end{array}$ & $\begin{array}{l}\text { ZHANG } \\
\text { Ruimin, Board } \\
\text { Chairman and } \\
\text { CEO }\end{array}$ \\
\hline Lenovo & 1984.11 .1 & $\begin{array}{l}\text { Computer and } \\
\text { office } \\
\text { equipment }\end{array}$ & $\begin{array}{l}\text { Global No.3 PC enterprise; ranking } \\
\text { No.231 in "Fortune" Global 500 in } \\
\text { 2014; sales volume in China domestic } \\
\text { market keeping to be No.1 since 1997. }\end{array}$ & $\begin{array}{l}\text { LIU Chuanzhi, } \\
\text { Honorary Board } \\
\text { Chairman }\end{array}$ \\
\hline Huawei & 1987.7 .27 & $\begin{array}{l}\text { Network and } \\
\text { communication } \\
\text { equipment }\end{array}$ & $\begin{array}{l}\text { Supplier of leading global information } \\
\text { and communication design solution; } \\
\text { ranking No.228 in "Fortune" Global } \\
\text { 500 in 2014. }\end{array}$ & $\begin{array}{l}\text { REN Zhengfei, } \\
\text { President }\end{array}$ \\
\hline
\end{tabular}

Collins and Porras (2006) thought that "a great visionary company absolutely does not need a charismatic and visionary leader; in fact, this kind of leader may be harmful to company long term development". But Chinese circumstances create a unique environment for Chinese enterprises: Under the background of Chinese later development transformation, culture stirring macro social environment is brought by reforming and opening policy; micro business environment of learning and innovation is created by modern transformation of traditional management thoughts. Affected by such macro and micro environment, it is possible for Chinese enterprises growing by introducing advanced foreign technology, business and management mode; also such environment enable characteristics of Chinese enterprises relying on outstanding leader being highlighted.

This has something to do with application of modern transformed ancient Chinese important ideas and principles of state governance to business management. Basing on Confucianism principle of "Respecting those noble men and appointing jobs for those talented persons", we find "Chinese enterprises development relying on outstanding leader" is in ancient Chinese management. Explanation of modern transformation of principle of "Respecting those noble men and appointing jobs for those talented persons" is as the following.

Confucius put forward that "gentleman ruling with humanity" ("Doctrine of mean • Chapter 13"), 
advocating national governance must rely on ethical and knowledgeable gentlemen who use humanity to administer people. Mencius once said "Respecting those noble men and appointing jobs for those talented persons" ("Mencius • Gongsun Chou first half"), i.e national governing must respect the ethical and use talented people, and must allow those who have the ability to govern the country. If regard those ethical, intellectuals, virtue and able mane as elite, previous principle can be described as: elite is indispensable for national governance; national governance must follow way of principle and law.

Such viewpoint raised by Confucius and Mencius did not emphasize governing country successfully, just as normative principles for national governance, stressing that national governance should be "Respecting those noble men and appointing jobs for those talented persons". However, feudal Chinese empire lasting forever was the governing ideal of ancient Chinese rulers. Long period stability, peace and prosperity were their governance objectives. If taking such objects as successful sign of ancient national governance, then in the eyes of Confucius, such rulers are saints, like Yao, Shun, Tang, Wen, Wu and Zhougong (all of them were famous ancient Chinese rulers). Taking them as outstanding national rulers, previous principle shall become as successful national governance absolutely needs prominent rulers; national governance must follow way of principle and law.

On this basis, we make conversion as follows: national governance $\rightarrow$ business management, outstanding nation ruler $\rightarrow$ outstanding business leader, way of principle and law $\rightarrow$ advanced business management method, national governing principle of "Respecting those noble men and appointing jobs for those talented persons" is converted to management principle of modern enterprise: outstanding leadership principle, i.e outstanding leader is indispensable for successful business management, and running enterprise must follow advanced management principle.

When we talk about the Chinese enterprise, especially that labeled as excellent, brilliant, outstanding and most respected, there must have a leader who is titled same reputation. To some extent, this shows that "management principle" derived from above phrase-conversion is proved in practice. Inspired by this, this thesis focuses on leadership in fast growing enterprises (including leaders and leader behaviors).

In summary, based on relevant theories and supported by historical heritage of Chinese traditional management thoughts, this thesis proposes the theoretical hypothesis: fast-growing enterprises possess outstanding leadership characteristics.

So, what kind of outstanding leaders do fast-growing enterprises have? How do these leaders carry out their leadership with advanced business management methods? Following case analysis contents shall deal with that. Case analysis framework is mainly pursuant to "excellent performance evaluation criteria" and aforementioned effect of Chinese context. Analysis framework is as Table 2. 
Table 2: Analysis Framework of Leadership Characteristics of Fast Growing Enterprises

\begin{tabular}{|c|c|c|c|}
\hline Construct & $\begin{array}{l}\text { Primary } \\
\text { Indicator }\end{array}$ & $\begin{array}{l}\text { Secondary } \\
\text { Indicator }\end{array}$ & Questions \\
\hline \multirow{19}{*}{$\begin{array}{l}\text { Enterprise } \\
\text { Leadership }\end{array}$} & \multirow[t]{6}{*}{ Leader } & \multirow{2}{*}{$\begin{array}{l}\text { (A) Entrepreneur } \\
\text { Role }\end{array}$} & (1)Whether the leader is entrepreneur or not? \\
\hline & & & $\begin{array}{l}\text { (2)Whether the leader is an outstanding } \\
\text { entrepreneur or not? }\end{array}$ \\
\hline & & \multirow[t]{2}{*}{$\begin{array}{l}\text { (B)"Politics- } \\
\text { Ethics" Role }\end{array}$} & $\begin{array}{l}\text { (3)Whether the leader is "politics - ethics" elite or } \\
\text { not in the Chinese circumstance or not? }\end{array}$ \\
\hline & & & $\begin{array}{l}\text { (4)What kind of "politics - ethics" elite is the } \\
\text { leader? }\end{array}$ \\
\hline & & \multirow[t]{2}{*}{ (C)Cultural Role } & $\begin{array}{l}\text { (5)Can the leader use modern } \\
\text { managiness } \\
\text { ment theories to guide his work? }\end{array}$ \\
\hline & & & $\begin{array}{l}\text { (6)Does the leader show inheritance and innovation } \\
\text { of Chinese traditional management thoughts? }\end{array}$ \\
\hline & \multirow[t]{6}{*}{$\begin{array}{l}\text { Enterprise } \\
\text { Culture }\end{array}$} & \multirow{3}{*}{$\begin{array}{l}\text { (D)Establishment } \\
\text { of Enterprise } \\
\text { Culture }\end{array}$} & $\begin{array}{l}\text { (7)Does the leader focus on culture construction } \\
\text { work? }\end{array}$ \\
\hline & & & (8)Does enterprise culture come into being? \\
\hline & & & $\begin{array}{l}\text { (9)Does enterprise culture acknowledged by } \\
\text { employees? }\end{array}$ \\
\hline & & \multirow[t]{3}{*}{$\begin{array}{l}\text { (E)Enterprise } \\
\text { Culture Content }\end{array}$} & $\begin{array}{l}\text { (10)Does enterprise culture promote innovation } \\
\text { not? }\end{array}$ \\
\hline & & & $\begin{array}{l}\text { (11)Does enterprise culture contain complete } \\
\text { management philosophy? }\end{array}$ \\
\hline & & & $\begin{array}{l}\text { (12)Does core values of enterprise point to rapid } \\
\text { growth? }\end{array}$ \\
\hline & \multirow[t]{2}{*}{$\begin{array}{l}\text { Performance } \\
\text { Goals }\end{array}$} & \multirow[t]{2}{*}{$\begin{array}{l}\text { (F) Short and } \\
\text { Long Term Goals }\end{array}$} & $\begin{array}{l}\text { (13)Does enterprise establish clear strategic } \\
\text { direction? }\end{array}$ \\
\hline & & & $\begin{array}{l}\text { (14)Does enterprise have short-term goals that } \\
\text { match strategic direction? }\end{array}$ \\
\hline & \multirow[t]{5}{*}{$\begin{array}{l}\text { Operation } \\
\text { Environment }\end{array}$} & \multirow[t]{3}{*}{$\begin{array}{l}\text { (G)Efficiency } \\
\text { System }\end{array}$} & $\begin{array}{l}\text { (15)Can the leader promote a clear authorization } \\
\text { and improve the work speed? }\end{array}$ \\
\hline & & & $\begin{array}{l}\text { (16) Can the leader enhance employee pressure and } \\
\text { responsibility? }\end{array}$ \\
\hline & & & $\begin{array}{l}\text { (17)Can the leader facilitate implementation of } \\
\text { performance related salary system? }\end{array}$ \\
\hline & & \multirow{2}{*}{$\begin{array}{l}\text { (H)Learning and } \\
\text { Innovation } \\
\text { Environment }\end{array}$} & $\begin{array}{l}\text { (18)Does the leader create a favorable innovation } \\
\text { environment for employees? }\end{array}$ \\
\hline & & & $\begin{array}{l}\text { (19)Does the leader create a good learning } \\
\text { environment? }\end{array}$ \\
\hline
\end{tabular}

\section{Case Analysis}

Then we start evidence analysis for Haier, Lenovo and Huawei, to explore their common characteristics. Analysis results obtained are as follows.

\section{Leader}

By summarizing answers to questions in the analysis framework, we find leaders of case enterprises are outstanding entrepreneurs in economic sense and are "politics-ethic" elites and cultural elites under Chinese context.

Since China's reform and opening, case enterprise leaders created development miracle from scratch, from small to large and from weak to strong. They led enterprises participating worldwide competition through globalization. Their enterprises have been listed in or near the world's top 500 . As outstanding entrepreneurs, they have the ability to effectively coordinate allocation of resources, 
are also engaged in "creative destruction," are taking "to enhance competitiveness" as core goal of enterprise development. So they have won series of awards and honors conferred by world and China, which prove the value of enterprise and individual.

They are excellent Communists, holding post within party organization. They have a higher political status, often involve in important political and social activities. They have high morality, attach importance to social responsibility, charity work. They are good example of enterprises, gain widely acknowledgement and respect.

Chinese ancient cultural elites not only bear rich Chinese cultural accomplishment in themselves, but also consciously practice the cultural enlightenment function in society. We take leaders of case enterprises as contemporary cultural elites, not because they are familiar with modern business management knowledge, but for their mastery of traditional Chinese culture, especially ancient Chinese philosophy, ancient management knowledge and such knowledge is used in their business management. Application of Chinese traditional management thoughts in modern business management is an important innovation practice of business leaders.

Table 3: Questions Analysis on Leader

\begin{tabular}{l|l}
\hline Conclusion Found & \multicolumn{1}{|c}{ Fact Evidence Found in Case Enterprises } \\
\hline Leaders are & Haier: "Chinese Most Valuable Brand List" (listed top for 13 years), "Global \\
distinguished & 50 Most Respected Business Leaders" (2005), "2015 Global Most Influential \\
entrepreneurs. & Management Thinkers and Ideas into Practice Award" (Thinkers 50), etc.
\end{tabular}

Lenovo: "FT China's Top Ten World-Class Brand" (2008), "Global 25 Most Influential Business Leaders"(2001), "Global 50 Most Influential Commercial Thinkers (2013) (Thinkers 50) ,etc.

Huawei: Listed 94 in "Best Global Brand Ranking"(Interbrand,2014), "'Wealth' No.1 of Most Influential Business Leaders"(2013), "'Times' Global 100 Most Influential Persons" (2013) etc.

Leaders are $\quad$ Haier: Deputy to14 ${ }^{\text {th }}, 15^{\text {th }}, 16^{\text {th }} 17^{\text {th }} 18^{\text {th }}$ CPC national congress; National politics-ethic elites outstanding communist in 2001 ; alternate member to $16^{\text {th }}, 17^{\text {th }} 18^{\text {th }}$ Central in Chinese Committee of Communist Party of China; National model worker; \begin{tabular}{l|l} 
circumstance. & performances social responsibility; cares for public welfare, charity, etc.
\end{tabular}

Lenovo: Vice-Chairman of All China Federation of Industry and Commerce; deputy to $16^{\text {th }} 17^{\text {th }}$ CPC national congress; deputy to $9^{\text {th }} 10^{\text {th }} 11^{\text {th }}$ National People's Congress; member of $11^{\text {th }}$ national committee of Chinese People's Political Consultative Conference(2008); most influential labor model since founding of China(2009); takes part in venture philanthropy.

Huawei: Stays away from the public media, low profile and mysterious; tactfully declined Vice-President of All China Federation of Industry and commerce and deputy qualification of National Congress.

Leaders are $\quad$ Haier: "You shall not understand Haier unless you use philosophy." Taoism cultural elites in and everything, there be and there be not etc by Laozi are skillfully used, as \begin{tabular}{l|l} 
Chinese & well as symbols, words and ideas in book of changes.
\end{tabular}

\begin{tabular}{l|l} 
circumstance. & Lenovo: Comprehensive use of MAO Zedong thoughts.
\end{tabular}

Huawei: "Management theories are permeated and blended with traditional philosophy of Confucianism, Legalism, Taoism etc, filled with strong dialectical color." "Pacesetter of learning MAO Zedong thoughts"; "From the realm of necessity to the realm of freedom".

\section{Enterprise Culture}

Case enterprises all have formed a unique culture, culture of "The side which has unity of purpose among its officers and men will win". Leaders play key role in establishment of enterprise culture which accompanies a deep leader imprint. Enterprise culture does not just stop at the level to express leader's personal thoughts, but through active and effective publicity, set an example by the 
leader personally, become shared values of all employees, play a guiding role at all levels of business activity.

Core of case enterprise culture is all to advocate innovation, to create value through innovation to facilitate enterprise to growing rapidly. The culture system comprehensively covers the entire business philosophy. The culture is the spirit and soul of enterprise, is common value system acknowledged by all employees. It guides employee behaviors in ideology, covering where rules and regulations of enterprise cannot reach.

Table 4: Questions Analysis on Enterprise Culture

\begin{tabular}{|c|c|}
\hline Conclusion Found & Fact Evidence Found in Case Enterprises \\
\hline \multirow[t]{3}{*}{$\begin{array}{l}\text { Establish } \\
\text { characteristic } \\
\text { cultural system }\end{array}$} & $\begin{array}{l}\text { Haier: "Haier culture is innovative value of leader acknowledged by all } \\
\text { employees." ZHANG is Haier's "chief cultural officer". Culture shows through } \\
\text { "Idea guide" principle, Haier dictionary, symbolic communication, instruction } \\
\text { in words, examples set by the leader personally, cartoon, "Haier employee" } \\
\text { newspaper and "paintings and words of Haier employees" etc. }\end{array}$ \\
\hline & $\begin{array}{l}\text { Lenovo: LIU believes that foundation of enterprise culture is the leader who } \\
\text { shall use his own conduct, ethics to drive the whole enterprise. }\end{array}$ \\
\hline & $\begin{array}{l}\text { Huawei: REN said "Resources will be exhausted, only culture survives." } \\
\text { "Culture is not something, but it is in everywhere." "Only those who } \\
\text { acknowledged Huawei culture are Huawei's fellow travelers." }\end{array}$ \\
\hline \multirow[t]{3}{*}{$\begin{array}{l}\text { Rich connotation } \\
\text { of cultural system }\end{array}$} & $\begin{array}{l}\text { Haier: Three levels of culture, "surface material culture, intermediate system } \\
\text { behavior culture, core values". "Core value of culture is innovation." "Haier } \\
\text { Culture Handbook". }\end{array}$ \\
\hline & Lenovo: "Ship Culture", "Engine Culture". \\
\hline & $\begin{array}{l}\text { Huawei: "Customer Focus, Struggler Foremost"; "Struggle Culture/Mattress } \\
\text { Culture"; "Service Culture and Integrity Culture";" Basic Huawei Norm" etc. }\end{array}$ \\
\hline
\end{tabular}

\section{Performance Goals}

Case enterprise leaders have forward-looking judgment for enterprise development. They can keenly grasp the future trend of things to go. They think actively with rich imagination. They have advanced judgment, thus determine a great plan for enterprise growing. Case enterprises all have established a clear strategy; and the overall goal of enterprise is divided into staged sub-goals, accordingly sub-strategies shall be established to achieve corresponding sub-goal at each stage.

Table 5: Question Analysis on the Performance Goals

\begin{tabular}{l|l}
\hline Conclusion Found & \multicolumn{1}{c}{ Fact Evidence Found in Case Enterprises } \\
\hline $\begin{array}{l}\text { Strategic } \\
\text { orientation } \\
\text { matches short-term } \\
\text { goals }\end{array}$ & $\begin{array}{l}\text { Haier: "Haier's goal is to create China's world famous brand, winning glory } \\
\text { for the nation."'Selfless Dedication, Pursuit Excellence"; "Rapid Response, } \\
\text { Immediate Action";"Create Resources, Worldwide Reputation". "Integrating } \\
\text { order (customer demand) with employee, quick decision, quick victory". }\end{array}$ \\
\cline { 2 - 3 } & $\begin{array}{l}\text { Lenovo: Its mission is " making great efforts to innovate for the interests of } \\
\text { customers, in specific, creation of most innovative products with first class } \\
\text { quality in the world ....." "Step by Step Approach" Strategy. }\end{array}$ \\
\cline { 2 - 3 } & $\begin{array}{l}\text { Huawei: Its vision is "enriching life and communication for people". Strategic } \\
\text { direction is "to be world-class, leading telecommunications equipment } \\
\text { suppliers". "Customer-Oriented Strategy"; "Encircling the cities from the rural } \\
\text { area market, gradually occupying city market" Strategy. }\end{array}$ \\
\hline
\end{tabular}




\section{Operation Environment}

Case enterprise leaders attach importance to authorization, and emphasize passing market pressure directly to each employee, thereby increasing pressure and sense of responsibility of employees, enhancing reaction speed and flexibility of enterprise, and to ensure implementation of pressure transferring, salary system related to individual performance was adopted. Enterprise builds an overall environment atmosphere that innovation is stressed and employee innovation is encouraged. Accordingly a complete set of personnel training system is established to help and encourage employees to continue to learn and actively enhance their self value.

Table 6: Question Analysis on Operation Environment

\begin{tabular}{l|l}
\hline Conclusion Found & \multicolumn{1}{|c}{ Fact Evidence Found in Case Enterprises } \\
\hline High efficiency & $\begin{array}{l}\text { Haier: "Shock-type" environment, market chain passes market pressure to } \\
\text { each employee; Complete results-based system, management of market } \\
\text { mechanisms are more thorough than those in Japan and in the United States; } \\
\end{array}$ \\
\cline { 2 - 2 } & "First Day Meeting", "10/10 Principle".
\end{tabular}
training process. Personnel training theory is first making insole before making suit, and Z-turn(Toss about) is the sole criterion for testing personnel. Incentive mechanism is material awards with spirit incentive.

Huawei: Treatment not only refers to money, but also includes allocation of duties and responsibilities. Without dependence, internal mechanism is always active with impending market pressure. Remuneration is determined by one's contribution and treatment is determined by one's duty.

Active learning and innovating environment Haier: Haier talent view; Everyone is SBU; "Reasonable Suggestions"; "Creative problem-solving meeting"; "Team Work Innovation Award". Lenovo: "Mold Training for Employee"; Running a company is how to develop and cultivate employees. "People-oriented" values since beginning. Huawei: "Cadres and Reserve Team Culture"; "Huawei University"; "He who experienced no suffering will not be a talent."

\section{Conclusion and Discussion}

Conclusions can be obtained through case analysis that: Case enterprises have outstanding leadership characteristics, which means leaders are outstanding entrepreneurs under economic category, and are also "political-ethic" elites and the cultural elites under Chinese context. They meanwhile own foresight leading behaviors.

(1)They have qualities of excellent entrepreneur and adept at using of internal and external resources. At initial period, they overcame shortage of funds and lack of resources, and led enterprise quickly gaining rapid development.

(2)They actively participate in social, political, charitable activity. They are excellent Communist party members, or deputies to people's congress, or political committee member or alternate member of Central Committee, and received many honorary titles such as model workers. They have been widely acknowledged and respected all over the country.

(3)Although at first they did not receive systematically education of modern western management theory, they soon introduced western management system to their enterprises through their tireless theory study and practical exploration. And considering actual enterprise situation, they established their own perfect management system.

(4)Under their leadership, high quality enterprise culture and development strategy soon was established, which laid the foundation for enterprise achieving good economic performance, expanding scale, enhancing competitive advantage and moving toward fast growing.

Fast-growing enterprises possess outstanding leadership characteristics, which are explained as having outstanding leadership is not only the important characteristics, but also the important reason 
for enterprises growing fast. And we also need to pay attention that there may exist slightly inferior outstanding leadership in non-fast-growing enterprises. Enterprises are difficult to obtain fast growing without it.

\section{Acknowledgements}

This research was supported by the Fundamental Research Funds for the Central Universities under grant No. $26120112011 B 09814$ \& No. $26120132013 B 12814$.

\section{References}

[1] COLLINS,J. and PORRAS,J.I. 2006. Built to Last: Successful Habits of Visionary Companies,(ZHEN,R. Trans.) China Citic Press: Beijing (Original work published 1994).

[2] HU,Y. and HE,Y.Z. 2015. History of Haier Innovation (1984 2014), China Machine Press: Beijing.

[3] FISHER,B., LAGO,U. and FANG,L. 2015. Reinventing Giants: How Chinese Global Competitor Haier Has Changed the Way that Big Companies Transform(CAO, Y.F. Trans.), China Citic Press: Beijing (Original work published 2013).

[4] HUANG,W.W. ETC. 2014. Dedication: The Foundation of Huawei's Human Resources Management, China Citic Press: Beijing.

[5] LI,H.G. 2015. Lenovo Reborn: Globalization Textbook for Chinese Companies, China Citic Press: Beijing.

[6] HE,S.L., ZHANG,Y. and LI,M.F. 2009. Management innovation research on Chinese enterprises: Form the perspective of western management theories and Chinese traditional management thoughts, The Thirteenth World Management Forum and Oriental Management Forum, Nanjing, Oct.30-Nov.1.

[7] YIN. R.K. 2004. Case Study Research: Design and Methods(3rd Edition)(ZHOU,H.T. Trans.), Chongqing University Press: Chongqing (Original work published 2002). 